\title{
Sabo Works: A Pioneering Experience in Brazil
}

\author{
Paulo T. da CRUZ 1, Faiçal MASSAD 1, Milton A. KANJI 1, Kokei UEHARA 1 \\ Hideki ISHITANI 1, Yasuko TEZUKA ${ }^{1}$ (In Memory) and Homero A. ARAÚJO FILHO 2 \\ 1 Escola Politécnica da Universidade de São Paulo \\ (Av. Professor A Imeida Prado 271, Tr.2 n.83, São Paulo-SP, 05508-070) \\ E-mail : ptcruz@terra.com.br \\ 2 PETROBRAS Avenida 9 de A bril, 777-Jardim das Industrias, Cubatão - SP 11525-090
}

\begin{abstract}
Debris flows are common phenomena along the "Serra do M ar", a mountain range of about 800 to $1000 \mathrm{~m}$ high, running along the Southern Brazilian coastal area. This paper deals with the "Sabo Works", i.e., structures to control debris-flows, proposed for an area of the "Serra do M ar", in Cubatão, São Paulo-Brazil. The Brazil-Japan cooperation in the mid-1980 is described, followed by a brief history of past events that affected a PETROBRAS large oil refinery located in the area. A description of the phenomenon and the conditions for its occurrence are presented. The concepts and functions of the proposed "sabo works" are pointed out, stressing that they intended to protect the refinery installations and to preserve the environment.
\end{abstract}

Key words: "sabo works", debris flow, design parameters, B razil-Japan cooperation

\section{INTRODUCTION}

This paper deals with the erosion and sediment control engineering works ("sabo works" to use a Japanese term), built along the Pedras River and its tributary to protect the installations of an oil refinery against the destructive action of debris flows. The refinery is located in Cubatão, State of São Paulo, Brazil, at the foot of the steep hill slope of the "Serra do $M$ ar" mountain range. Officially called Refinaria Presidente Bernardes Cubatão (RPBC), it is an important unit of PETROBRAS, the largest oil company in Brazil, mainly for its characteristics of being the most complex one, producing a great variety of products. Its annual production is about 200,000 barrels per day.

As the area is densely occupied by chemical and processing industries, the discharge of pollutants to the atmosphere has affected the vegetation of the hill slopes, causing its degradation, either by direct incidence or by acid rains. Although an aggravating factor, this may not be solely responsible for the landslides and debris flows, since the geological inspections of the river deposits have shown that these phenomena has been recurrent in the last thousand years.

In addition an old road, "Caminho do M ar", which crosses the basin along the mountain range, was at that time out of use and without proper maintenance, particularly as far as its drainage system was concerned. The excess water drained by the road poured into the basin, increasing the erosion problems, and the amount of loose material that was easily incorporated to a debris flow.

Preservation of the natural landscape, against erosion and sediment transport, and protection of the natural vegetation were also of basic concern in the design of such "sabo works".

Although "sabo works" have a long history in countries like A ustria and Japan, it is a pioneer activity in Brazil, that benefits from the world-wide experience regarding economy and effectiveness.

It is worth mentioning the technical visit carried out by some of the authors to Japan, in 1996, to learn from the J apanese expertise in this field of knowledge.

\section{THE BEGINNING OF THE BRAZIL- JAPAN COOPERATION}

Due to the occurrence of various events of landslides and debris flows on the slopes of the Serra do $\mathrm{Mar}$ (Table 1), whose consequences were serious and disastrous for industries or infrastructure works, located in Santos, geological and geotechnical studies were developed to characterize these phenomena in the mid-1980. At the end of the decade, São Paulo State Government requested the Japanese Government studies on debris flows, both for prevention and for their control. This was done by JICA (Japan International Cooperation A gency), between November 
Table 1 Past major debris flows in Serra do Mar, Cubatão Region

\begin{tabular}{|c|c|c|c|c|c|}
\hline \multirow{2}{*}{ PLACE } & \multirow{2}{*}{ DATE } & \multirow{2}{*}{ STREAM } & \multirow{2}{*}{$\begin{array}{c}\text { TOTAL } \\
\text { AREA }\left(\mathrm{km}^{2}\right)\end{array}$} & \multicolumn{2}{|c|}{ MAX. RAINFALL (mm) } \\
\hline & & & & 1 hour & 24 hours \\
\hline $\begin{array}{l}\text { MOGI RIVER } \\
\text { BASIN }\end{array}$ & $\begin{array}{c}24-27^{\text {th }} \\
\text { Feb } 1971\end{array}$ & MOGI RIVER & 30.60 & - & - \\
\hline \multirow[t]{2}{*}{ COPEBRAS } & \multirow{2}{*}{$\begin{array}{c}28^{\text {th }} \\
\text { Jan } 1976\end{array}$} & CACHOEIRA STREAM & 4.00 & \multirow[t]{2}{*}{39} & \multirow[t]{2}{*}{276} \\
\hline & & BRAÇO NORTE STREAM & 1.60 & & \\
\hline \multirow{2}{*}{$\begin{array}{c}\text { RPBC AND } \\
\text { PEREQUE } \\
\text { BASIN }\end{array}$} & \multirow{2}{*}{$\begin{array}{l}22-24^{\text {th }} \\
\text { Jan } 1985\end{array}$} & PEREQUÊ RIVER & 11.40 & \multirow[b]{2}{*}{84} & \multirow[b]{2}{*}{265} \\
\hline & & PEDRAS STREAM & 2.64 & & \\
\hline $\begin{array}{l}\text { PEDRAS BASIN- } \\
\text { ELETROPAULO }\end{array}$ & $\begin{array}{c}20-22^{\text {nd }} \\
\text { Jan } 1988\end{array}$ & PEDRAS RIVER & 3.40 & 25 & 135 \\
\hline \multirow{2}{*}{ RPBC } & $6^{\text {th }}$ Feb 1994 & PEDRAS STREAM & 2.64 & 60 & 214 \\
\hline & $9^{\text {th }}$ Mar 1996 & $\begin{array}{l}\text { MAIN TRIBUTARY OF } \\
\text { PEDRAS STREAM }\end{array}$ & 0.80 & 18 & - \\
\hline
\end{tabular}

Note: All the data were obtained from JICA [1991] except those related to the events of $6^{\text {th }} \mathrm{Feb} / 1994$ and 9th Mar/1996, which came from Massad et al. [1997].

/1989 and September/1990.

JICA sent to Brazil a study team that held discussions with the Brazilian officials and conducted field surveys. The objectives of the studies were: a) to formulate a master plan to prevent disasters and to select a priority project; b) to conduct a feasibility study on the priority project; and c) to promote technical transfer to the Brazilian counterpart personnel. The Final report was delivered in January/ 1991.

The studies involved twelve "sabo" basins and the predicted investments amounted to US\$ 50 million at that time. Due to the political and economic situation of Brazil, this study has not been made.

\section{A BRIEF HISTORY OF THE EVENTS}

Since its construction, summer rains of high intensity have caused problems to the Refinery. Until 1984, the consequences were the silting of the fresh water reservoir and the accumulation of leaves, tree branches and mud in the area, without any apparent risk to the installations.

However, in January 1985, a heavy rain caused the sliding of hillside slopes of the Pedras River basin with invasion of mud, gravel and tree branches to the reservoir in the Northern area. A long the year of 1985, protection works were built, including a concrete wall surrounding the reservoir and nine gabion dams along the Pedras River and its tributary.

In 1992, a new slide in two others hillsides led to the construction of additional protection works, including concrete walls surrounding tanks and 8 gabion dams in two other creeks. Photo 1 shows an aerial view of the region before 1994.

In 1994 a large debris flow reached the Refinery causing damage to its East, West and North areas (Photo 2). The "horto", a small area covered with trees, and 8 of the 9 gabion dams of the Pedras River were completely destroyed. The debris flow transported a volume in the order of $300,000 \mathrm{~m}^{3}$ of mud, sand, gravel, large rocks and trees, reaching tanks of the North area (Photo 3), the administrative buildings, the majority of the internal routes and almost all the processing units (Photo 4). This large accident resulted in 10 days of no oil production, at a cost of US\$ 44 million.

Prior to the 1994 debris flow the creeks were only 2 to $3 \mathrm{~m}$ wide and hardly visible due to the vegetation. After the debris flow, they suffered heavy erosion, enlarging to about $30 \mathrm{~m}$ and up to $40 \mathrm{~m}$ in some places. Air photos taken before and one month after the event (Photos $\mathbf{1}$ and $\mathbf{2}$ ) reveal the dramatic changes. Photo 5 shows the erosion along both creeks and the initial deposits at the feet of the slopes, after the February 6, 1994 event.

Although the Main Tributary stream is shorter than the Pedras stream, it is steeper and the erosion was 


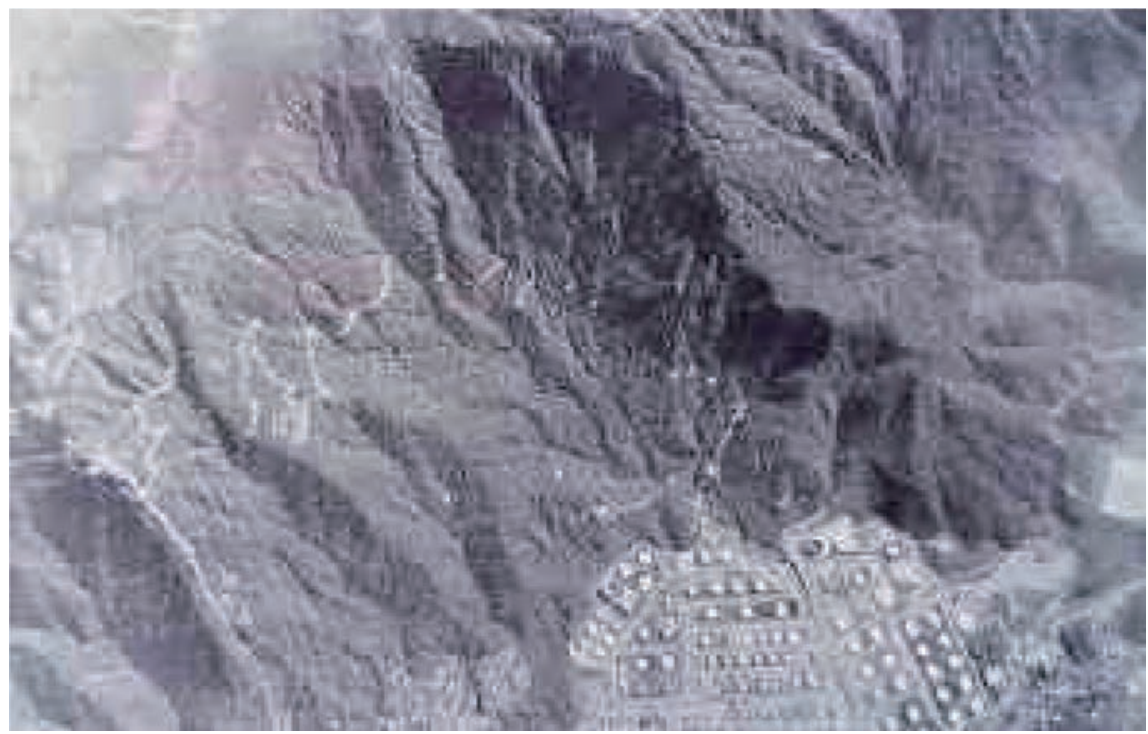

Photo 1 A erial view of the region before the 1994 debris flow.

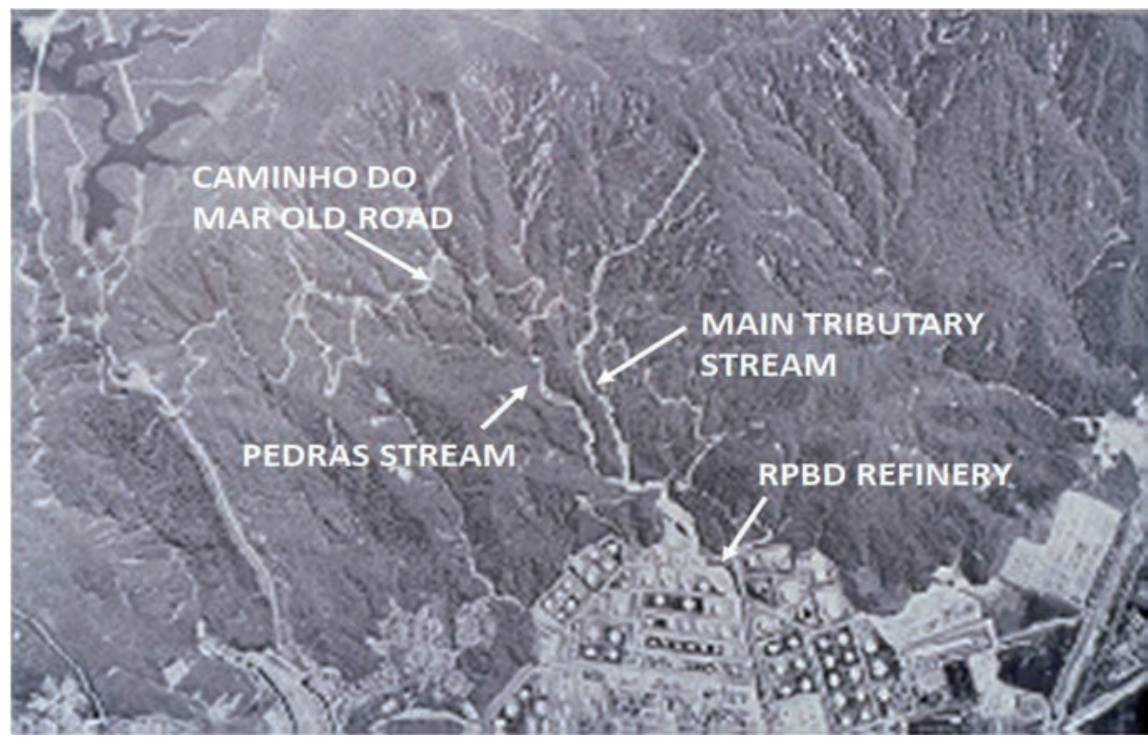

Photo 2 A erial view of the region affected by 1994 debris flows, showing eroded streams, landslide scars and the Refinery (RPBC).

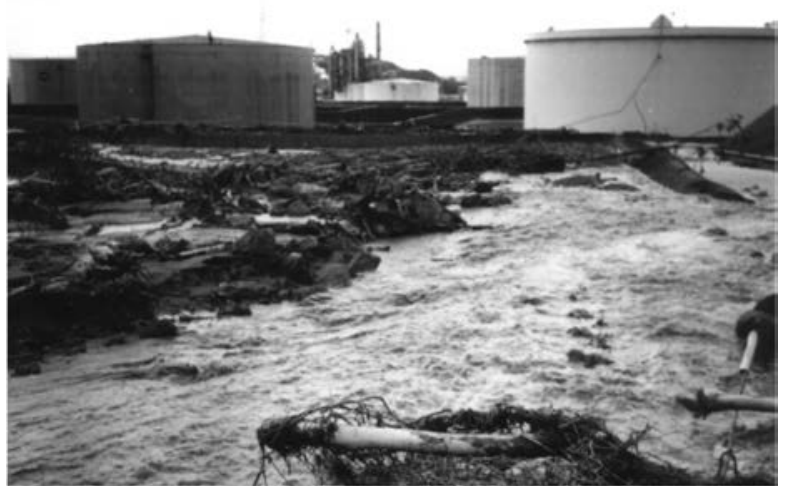

Photo 3 Destruction of protection dykes and invasion of tanking area.

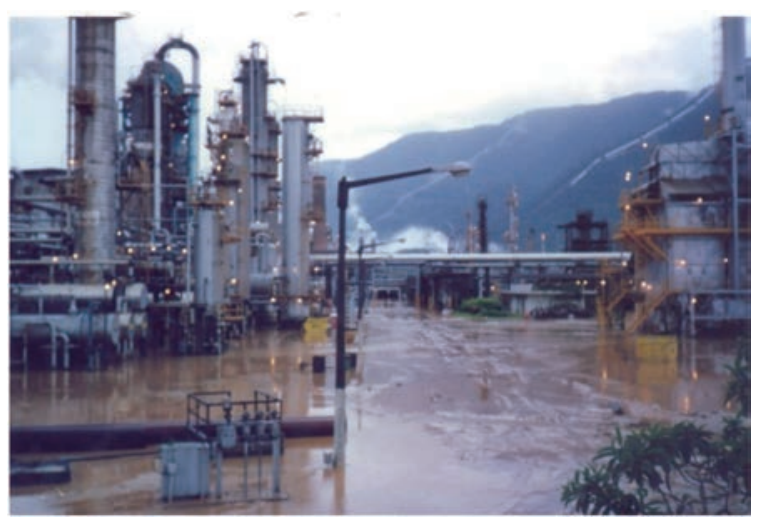

Photo 4 Flooded of the processing units area with mud and water. 


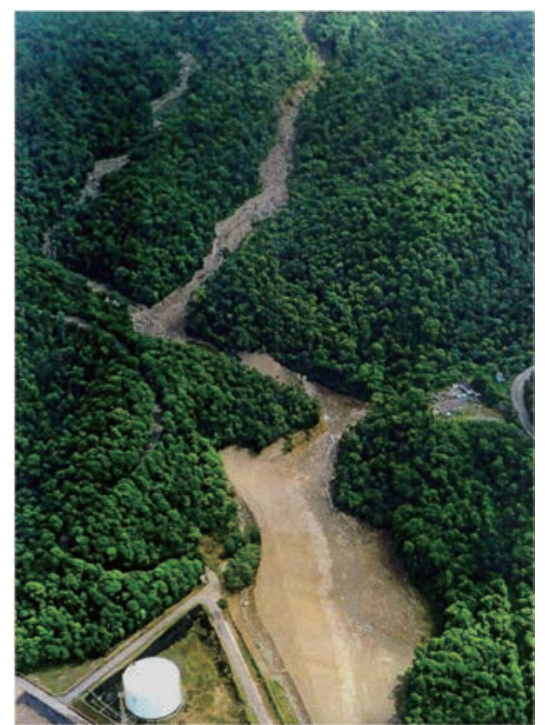

Photo 5 Enlarging of the river beds due to heavy erosion.

more intense.

A view of the debris deposits along the $M$ ain Tributary of Pedras Stream is shown in Photo 6. Several lobes with frontal accumulation of larger boulders are evident, indicating that several pulses had occurred during the 1994 debris flow.

\section{THE BRAZIL-JAPAN COOPERATION RESUME D}

After the event of Feb., 1994, PETROBRAS sought the help of a multidisciplinary team of 6 experts to study the problem and propose engineering works to control or at least mitigate the consequences of another debris-flow that could occur again in the same river.

Countries like Japan and A ustria, among others have been building protection works for more than a century.

To learn from the Japanese expertise in this field of knowledge, the Brazilian experts carried out a technical visit to Japan.

The visit was made under the partnership between São Paulo University and Osaka University. The technical visit included various contacts, including: research centers and laboratories of universities; Japanese Government agencies, responsible for the execution of the "sabo works"; and the office of a consulting firm (designer). Many "sabo works" in the vicinity of Tokyo, Osaka, Kobe and Hiroshima were visited.

What was most impressing was the large number of dams along the same river, forming successive levels that provide the break of the energy and retention of the sediments.

The projects of the "Sabo dams" are based on

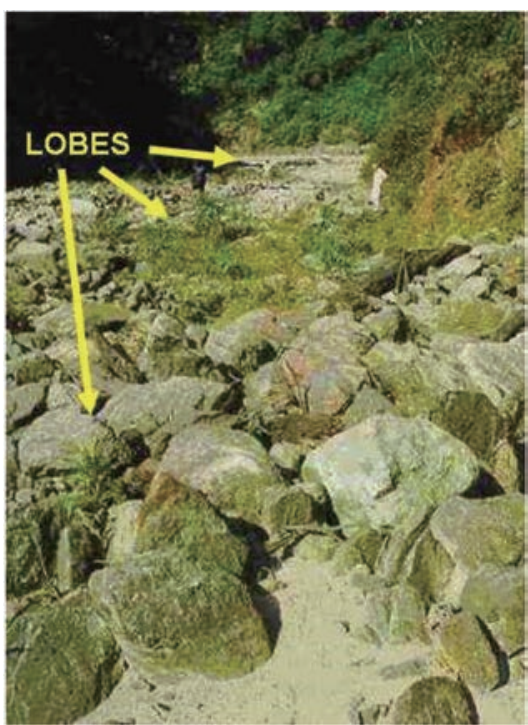

Photo 6 View of the debris deposits with lobes.

accumulated experience ("design by precedent") and the required design parameters depends greatly on the historical knowledge of previous events, on the determination of rain intensity, on the empirical formulae derived from other events and some theoretical formulae. In the case of steel frame dams the manufacturer provides the structural design. However, there are manuals that are rigidly followed. $M$ any manuals and technical documents were made available.

The major concern in the design of sequences of "sabo works" is the ability of sediment retention, by dams and reservoirs, or its conduction by channels.

\section{DEBRIS FLOWS CHARACTERISTICS}

Debris flows are phenomena of mass movements that occur quickly, in seconds or in a few minutes, with high capacity of erosion and destruction. Velocities as high as $70 \mathrm{~km} / \mathrm{h}(20 \mathrm{~m} / \mathrm{s})$ can take place, disclosing high impact forces (30 to $1000 \mathrm{kPa}$ ); the peak discharge may reach 5 to 20 times, or even more, the flood discharge. Among the natural hazards, they are responsible for the loss of lives and destruction of houses, industrial plants, natural resources, roads, etc. due to their large destructive power.

They usually take place within long and intense periods of rain 6 to $10 \mathrm{~mm}$ in 10 minutes, according to Suwa [1989], and leading to landslides. The water mixes with the clay and silt fractions, forms a mud that starts to flow downhill, transporting sand, gravel, large boulders, rock blocks and trees that reach long distances, even in flat slopes $\left(4^{\circ}\right.$ to $\left.8^{\circ}\right)$. Part of the "river" bed deposit is incorporated to the process, increasing the solid mass of the flow. The erosion of 
the margins tends to enlarge the "river" bed. The solid concentration, in volume, may range from $30 \%$ to $70 \%$.

The movement of the mass is peculiar: the rock fragments move on top of the mud layer (water plus soil fines), at a higher speed, until the slope becomes flatter or the flow spreads into a larger area. Then, the thickness of the mud layer reduces, the rock fragments tend to fall and block the remaining flow. The accumulation of debris behind this "temporary dam" can destroy or overtop it and continue to flow. This particularity can give the debris flow a wave characteristic.

\section{CONDITIONS FOR DEBRIS FLOWS OCCURRENCE}

Landslides, debris flows, mud flows, river erosion and sediment transport are common phenomena along the "Serra do Mar", a mountain range of about 800 to $1000 \mathrm{~m}$ high, running along the B razilian coastal area.

The basic conditions for the occurrence of debris flows in tropical countries are:

a) the inclination of the hillslopes and of the river channel ; most commonly they start at inclinations greater than $25^{\circ}$ to $30^{\circ}$;

b) the availability of loose material, as alluvial and colluvial deposits, or a thick mantle of residual soil that could be removed or displaced to contribute to the debris flow formation; and

c) the rainfall, which is the main triggering factor; recorded cases show that a rain intensity of about $1 \mathrm{~mm} / \mathrm{min}$, occurring during several minutes, can trigger a debris flow, provided that it has been preceded by at least a few days of rains of smaller intensity.

The Cubatão area satisfies all these conditions due to its geologic, geomorphologic and hydrologic aspects.

The bed rock of the basin area of the Pedras River is represented by gneissic rocks, weathered at the surface. The residual soils have a significant thickness in the upper elevation (600-800 $\mathrm{m}$ above sea level), and can easily slide due to the high steepness (above 35 degrees) and the occurrence of high intensity concentrated rains. In the intermediate area, at lower elevations $(\sim 300 \mathrm{~m})$, there are the presence of deposits of colluvium (clayey-sandy soils with rock boulders) and alluvium deposits in the river bed (mainly sands, gravel and rock boulders). These rock blocks have normally metric sizes (1.5 to $2 \mathrm{~m}$ ) but, exceptionally, blocks up to 6 or $7 \mathrm{~m}$ in "diameter" can be found that have been transported by the very high energy of debris flows.

The Refinery is partly located in an area of gneisses and mica-schists and partly on a flat area of marine sediments. Several parts the area is covered by recent deposits, either alluvium (from river sediments or debris flows) or colluvium (from the closer hillsides).

The river bed, currently 20 to $40 \mathrm{~m}$ width, and the abutments change continuously during summer floods. The thickness of the river bed sediments can reach 8 $\mathrm{m}$, as measured in borings, and may be incorporated to debris flows as well as the colluvium from the river margins.

Annual mean rainfall in the area is around 3,000 $\mathrm{mm}$ and the mean temperatures fluctuate from 20 to $25^{\circ} \mathrm{C}$ throughout the year.

\section{CRITERIA FOR SITE SELECTION}

The history of previous events that affected the Refinery (Table 1) was important in the direction of the studies and the planning of protection "sabo works" against the action of "debris flows".

A $n$ analysis of the flow conditions showed that the Main Tributary of the Pedras River presents a high slope and is "rectilinear" practically in its full extension, which favors the acceleration of the motion of a "debris flow". This situation was highlighted on the occasion of the "debris flow" of 1994, which significantly broadened the bed of this affluent, whose width has gone from a few meters to 30 to $40 \mathrm{~m}$. A third factor refers to the retaining works carried out along the "Caminho do Mar", the old road that cuts the Pedras River basin, promoting the flow control, but leaving unprotected the bed of the Main Tributary. For these reasons, the work of fixing the bed was necessary in this tributary.

The location of the dams was defined in terms of the geological (in rock) and topographic (ease of access) conditions. Permeable concrete dams BF-1, BF -2 and B-5 were built in the middle of the mountainous region, between elevations 70 and $130 \mathrm{~m}$, in places of easy access and with outcrops of rock. The exceptions were Dams BS-1 and BS-2, built in low level $(50 \mathrm{~m})$, resting on alluvium.

Finally, some of the works already existed, as the reservoir W 10 and the buried pipelines in the East A rea (ARLE). These existing works were significantly expanded and their storage capacities and outlets, respectively, more than tripled.

\section{THE DESIGN PARAMETERS}

The inherent difficulties in designing debris flow control works are related to :

a) the velocities;

b) the hydrographs and "debrisgraphs", i. e., the hydrograph of a debris-flow ;

c) the volume of sediments transported by the debris -flow ; 
d) the peak debris-flow discharge ;

e) the impact forces and pressures applied to the structures; and

f) the concentration of solids.

In addition it becomes very important to clearly define :

a) the shape of the hydraulic basin, whether spread with small tributaries, bringing water and sediments to the main river, or mostly straight and concentrated in one main river ;

b) the length, inclination, and the total height of the basin ;

c) the rain regime and the frequency of highly concentrated rain peaks;

d) the back history of the site, and the register of past debris-flows;

e) the nature of slopes, vegetation, thickness of soil, boulder concentration, unstable rock slopes, etc.; and

f) the local climate.

Any use of formulae from the literature, must be adjusted to the local conditions and, whenever possible, cross checked by different approaches.

M ore detailed discussion of the theme is presented by Cruz \& Massad [1997]. In continuation, the formulae used in Brazil, for the design of control works, will be mentioned.

\section{Velocity}

The velocity may be computed by Rickenman's [1991] formula as :

$$
v=1.3 \cdot \sin ^{0.2}(\theta) \cdot q_{0}^{0.6} \cdot \frac{g^{0.2}}{d_{50}^{0.4}}
$$

where $\theta$ is the slope; $g$, the acceleration of gravity, in $\mathrm{m}^{2} / \mathrm{s} ; d_{50}$, the average grain size, in meters; and $q_{0}$, the specific discharge flow, in $\mathrm{m}^{3} / \mathrm{s} / \mathrm{m}$, given by :

$$
q_{o}=\frac{Q_{o}}{b}
$$

b is the channel width, in meters, and $Q_{0}$ is the 100 year estimated water discharge for the basin.

The $d_{50}$ size was determined by in situ large scale grain size analyses of a debris-flow deposit [Massad et al., 1997].

This formula (1) has given reasonable values in back analysis of debris-flows.

\section{The hydrograph and the "debrisgraph"}

Debrisgraphs can be drawn considering the rain intensity, the contribution area, the runoff coefficient and the average slope of the basin. The peak discharge can be 10 to 20 times larger, but the time interval will be $1 / 30$ to $1 / 60$ times smaller.

To the authors' knowledge there are no mathematical formulae to build a "debrisgraph" because it may vary quite widely from site to site.

Factors as size of the basin, average slope, "river" course, vegetation, nature of rain, climate and anthropic occupation of the area affect the shape and magnitude of "debrisgraphs". Some mathematical models have been developed (see, for instance, Takahashi [1991 \& 2007], but the input data required may be so difficult to get that the results may be questionable.

\section{The peak discharge}

Araya Moya [1994] proposed a formula to estimate the peak discharge of a debris-flow, based on his experience with Chilean debris-flows:

$$
q_{T}=1.4 \cdot \frac{1}{(1-c)} \cdot 0.85 \cdot A \cdot I \cdot \frac{H^{0.19}}{L^{0.58}}
$$

where $c$ is the solid concentration in volume; $A$, the basin area, in $\mathrm{km}^{2} ; \mathrm{l}$, the average intensity of rain in 24 hour $(\mathrm{mm} / \mathrm{h}) ; \mathrm{H}$, the maximum difference in height within the basin, in $m$; and $L$, the total length of the torrent, in $\mathrm{km}$.

Based on back analysis of some Japanese and Brazilian data, Massad et al. [1997] proposed to replace I by $I_{1}$, $i$. e., the amount of rain in the hour that precede the debris flow, in $\mathrm{mm} / \mathrm{h}$. This replacement proved to fit better the events backanalyzed.

\section{Volume of sediments}

$M$ any authors have tried to correlate the peak discharge $q_{T}$ with the total volume of debris-flows $V_{T}$, based on empirical data. From the data presented by Takahashi [1991] it was possible to derive the following equation :

$$
V_{T}=500 \cdot q_{T}
$$

\section{Impact forces and pressure applied to the structures.}

The impact forces can be estimated by :

$$
F=\alpha \cdot A \cdot \gamma \cdot v^{2} / g
$$

where $\alpha$ is a coefficient that varies from 1 to $2 ; \mathrm{v}$, the velocity; $r$, the density of the debris-flow (unit 
weight) ; $g$, the acceleration of gravity and $A$, the area of impact.

\section{Concentration of solids}

The parameter $c$, the solid concentration in volume, can be computed by the formula [Takahashi, 1991] :

$$
c=\gamma_{0} \cdot \frac{\tan \theta}{\left(\delta-\gamma_{0}\right) \cdot[\tan \phi-\tan \theta]}
$$

where $\gamma_{0}$ is the density of the mud (water plus fines) ; $\delta$, the specific gravity of the solid grains; $\phi$, the friction angle of the granular material, and $\theta$, the average slope.

The same formula can be rearranged to define the critical angle $\theta$, or the average slope angle, in which a debris-flow will occur for particular values of $\gamma_{\circ}$ and $\phi$.

\section{DESIG N ASSUMPTIONS CRITERIA ADOPTED}

AND

The dams, concrete or steel frame, were designed statically, according to the current practice, with the inclusion of impact forces. The dissipation basins and the "subdams" were designed according to the usual principles of hydraulics. The steel frame dams were "gabion type" dam, but using steel frames instead of wires for the boxes filled with gravel (BS-1 and BS-2).

The main structures of the dams were designed for a "debris flow" associated with a $60 \mathrm{~mm}$ rain in 1 hour, as in the 1994 event, which corresponds to a period of recurrence exceeding 100 years. For secondary structures (basins of dissipation and "subdams"), this figure was $40 \mathrm{~mm} / \mathrm{h}$, aimed to economy. The inflow peak discharges in the dam B-5, the most important "sabo work", was $620 \mathrm{~m}^{3} / \mathrm{s}$ considering $60 \mathrm{~mm}$ rain in 1 hour, and $400 \mathrm{~m}^{3} / \mathrm{s}$ for $40 \mathrm{~mm}$ rain in 1 hour. The outflow peak discharge from the reservoir $W-10$ was estimated at $65 \mathrm{~m}^{3} / \mathrm{s}$ to a $60 \mathrm{~mm}$ rain in 1 hour. The $W$ - 10 Reservoir was designed to hold $72,000 \mathrm{~m}^{3}$ of sediments, which represents $55 \%$ of the capacity of the whole system, which is in the order of $130,000 \mathrm{~m}^{3}$.

Evaluations made subsequently showed that the projected works would be capable of supporting a "debris flow" caused by most severe rains, about 90 $\mathrm{mm}$ in 1 hour, because of gaps in the flow capabilities of the spillway overflows and retention of reservoirs. Sediment storage capacity increased to $165,000 \mathrm{~m}^{3}$. Peak discharges corresponding to this limit are shown in the lower parts of Fig. $\mathbf{1}$ that, moreover, displays the sequence of the implemented works.

\section{CONSTRUCTED “SABO WORKS"}

The engineering works to control a debris flow ("sabo works") require a clear understanding of the phenomena and a sequence of works, which play different functions, as pointed out by Ikeya [1976 \& 1989], Mizuyama and Ishikawa [1988], Legowo [1990], and Heumader [2000]. The "sabo works" proposed to the Refinery are sketched in Fig. 1 and Table 2, with pertinent data, and are shown in Photos 7 to 20.

The debris flows can be originated from the higher elevations of both the Pedras River and its tributary. The peak discharge flow from both rivers was estimated in $900 \mathrm{~m}^{3} / \mathrm{s}$.

The BF-1, BF-2 (Photos 8, 11 to 13) and BF-3 are "dams", 3 to 6 meters height on the spillway sections, built with the main purpose of breaking energy and partially retaining rock blocks and tree branches, but with a small effect on the discharge flow due to the small capacity of their reservoirs.

The B-5, a concrete dam, constructed with $8 \mathrm{~m}$ high in the spillway section (photo 14), is the main dam for debris flow control. It has a storage capacity high enough to reduce the peak discharge from $620 \mathrm{~m}^{3} / \mathrm{s}$ to $416 \mathrm{~m}^{3} / \mathrm{s}$ (Fig. 1).

The BS-1 and BS-2 (Photos 15 and 16) are two small check-dams, with spillway heights of $4 \mathrm{~m}$, having a relatively small storage capacity but they are able to reduce the peak flow from $416 \mathrm{~m}^{3} / \mathrm{s}$ to $334 \mathrm{~m}^{3} /$ s. The left abutment, from the B-5 to the BS-2 dam, is fully protected with steel crib type structures, to the maximum water level, and with natural vegetation at higher elevations. The right margin is a dike (Photo 15), also protected with steel crib type structures. The crest of the dike is also the access road to the reservoirs of B-5, BS-1 and BS-2 dams. These reservoirs will have to be emptied after the rainy season or after a debris flow.

In the sequence follows the large storage reservoir W-10 (Photo 19), that should retain all the material (mainly sand, silt and tree branches) transported over the previous dams in the event of debris flows; it can accumulate $80,000 \mathrm{~m}^{3}$ of debris. The peak flow is also drastically reduced from $334 \mathrm{~m}^{3} / \mathrm{s}$ to $65 \mathrm{~m}^{3} / \mathrm{s}$ (Fig. 1).

In the East side area, after the spillway of the W 10 reservoir, "sabo works" consist mainly of galleries, pipes and channels that are capable to discharge the flow into a plunge pool. From that point on, the muddy water is directed by a natural course to the Perequê River.

For more information on the design parameters used in these works see Cruz et al. [1997] and Kanji et al. [1997].

L ow-cost works were also undertaken.

a) To reduce the contribution of riverbed material, 

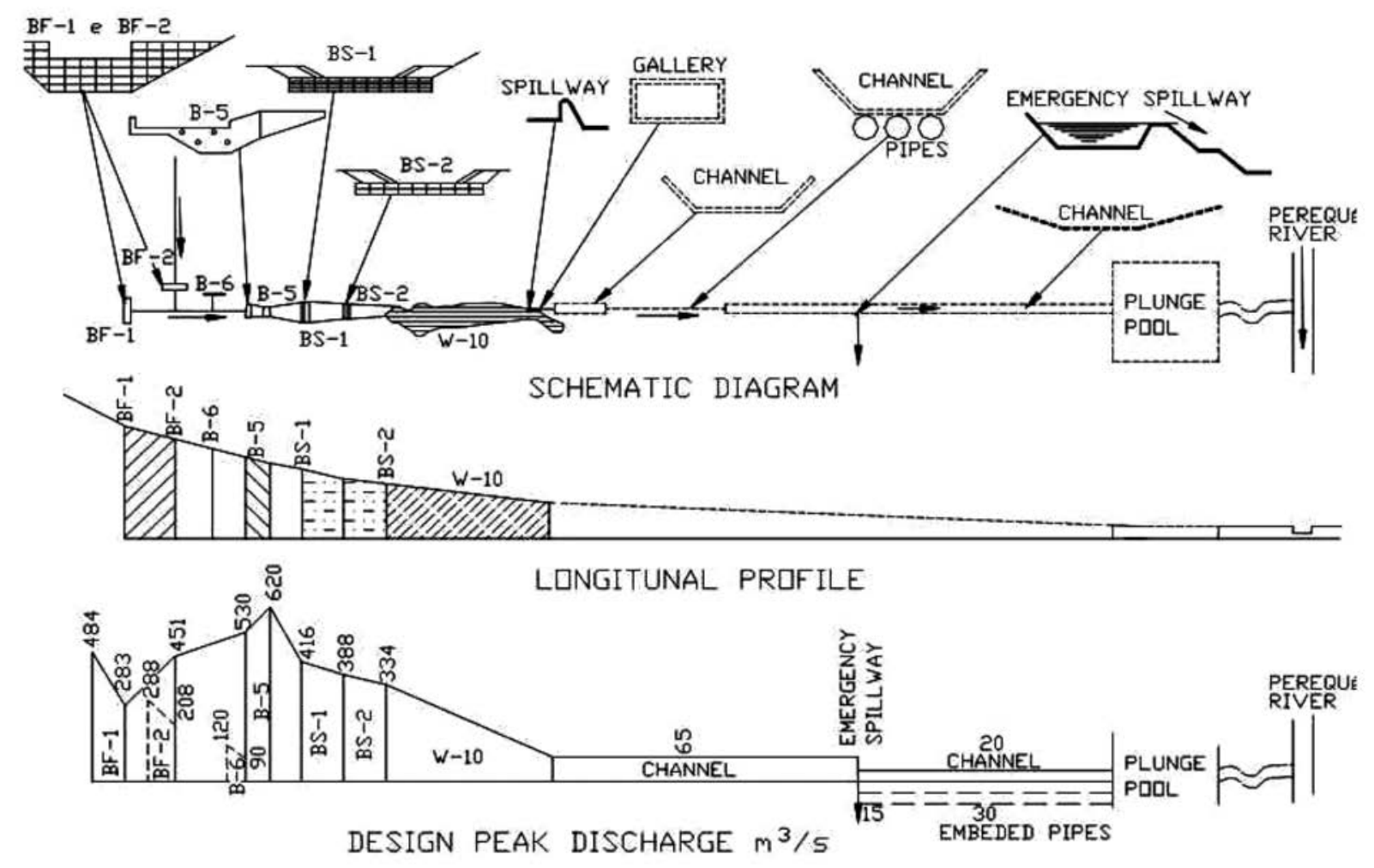

Fig. 1 Proposed sequence of works for the North basin.

Table 2 M ain Dam Dimensions

\begin{tabular}{|c|c|c|c|c|c|}
\hline \multirow{2}{*}{ Dam } & \multicolumn{2}{|c|}{ Height $(\mathrm{m})$} & \multirow{2}{*}{\begin{tabular}{c} 
ch \\
\cline { 5 - 6 }
\end{tabular}} & \multicolumn{2}{|c|}{ Dissipation basin slab (m) } \\
\cline { 2 - 3 } \cline { 5 - 6 } & Maximum & At spillway & & Width & Length \\
\hline BF-1 & 13.5 & 9.5 & 6.8 & $\sim 24$ & 18 \\
\hline BF-2 & 9.5 & 7.5 & 5.0 & 24 & 18 \\
\hline B-5 & 16.0 & 11.0 & 10.0 & 32 & 25 \\
\hline BS-1 & 7.5 & 3.0 & 2.0 & $\sim 28$ & 11 \\
\hline BS-2 & 6.0 & 3.0 & 2,0 & 20 & 11 \\
\hline
\end{tabular}

Note: $\Delta \mathrm{h}$, difference in level between spillway and dissipation basin slab.

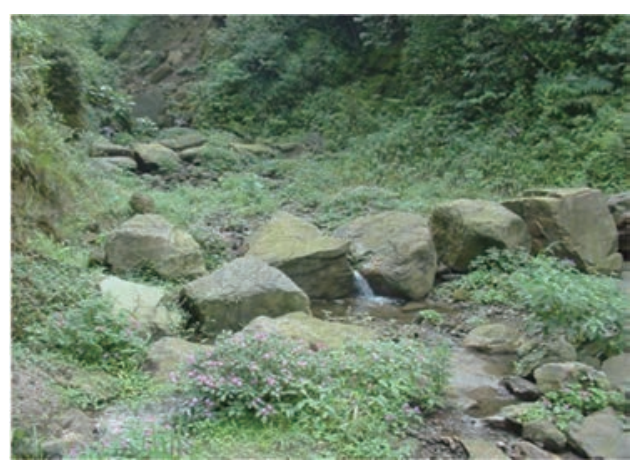

Photo 7 Stone Collars C 1.

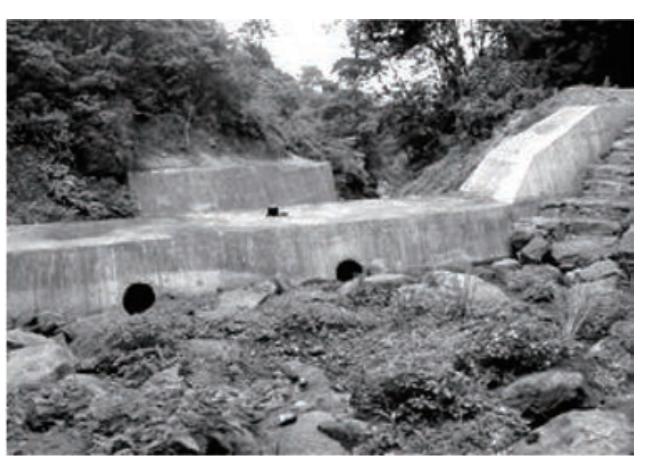

Photo 8 Upstream View of the BF 3 Dam. 
International J ournal of Erosion Control Engineering Vol. 11, No. 3, 2019

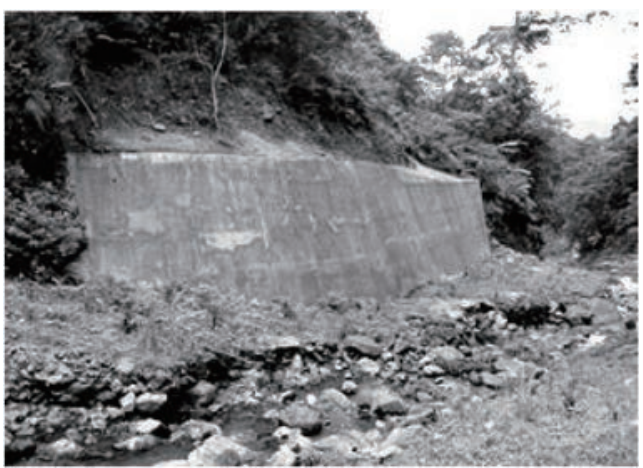

Photo 9 Concrete wall M 1 to prevent bank erosion.

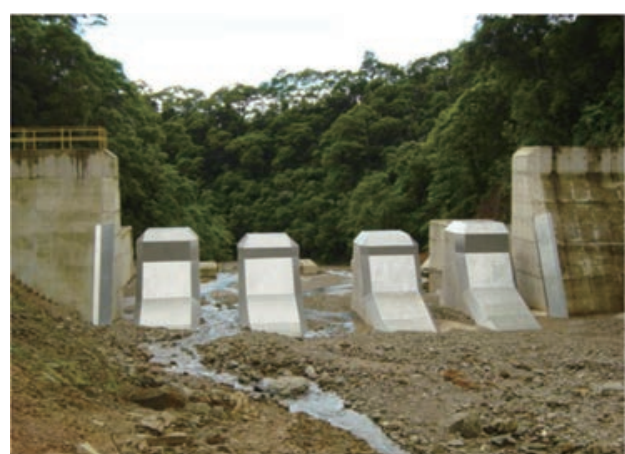

Photo 11 Slot dam BF 2 to break the debris flow energy.

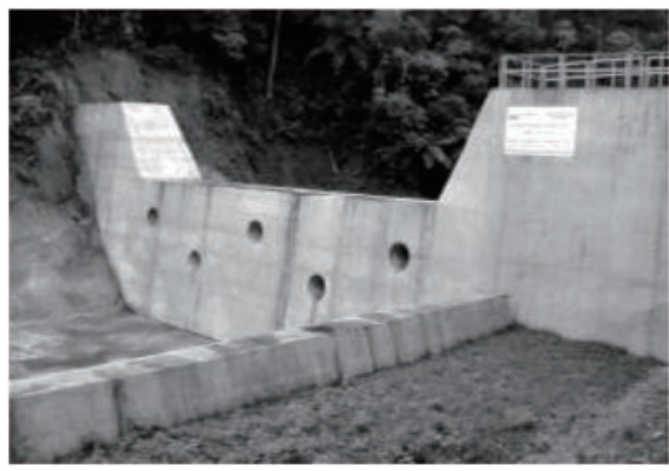

Photo 13 BF 1 Dam, breaking energy, partially retaining rock blocks.

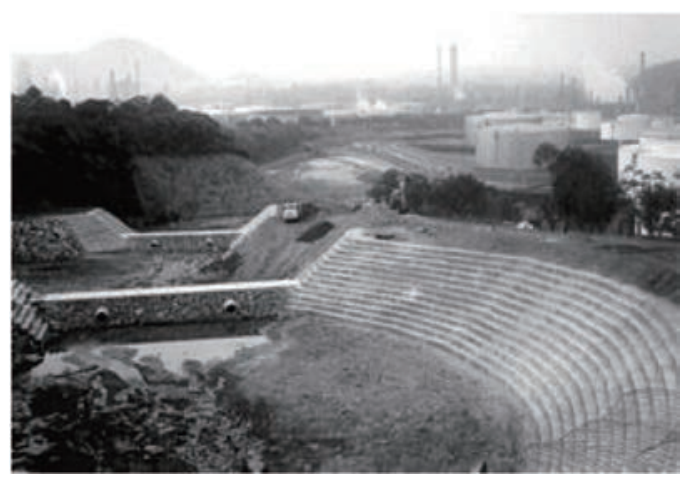

Photo 15 The BS-1 and BS-2 dams and dike protected with steel crib.

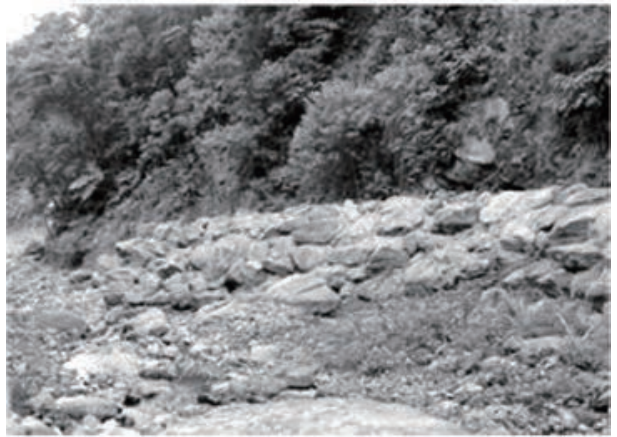

Photo 10 Rockfill cemented with mortar to prevent bank erosion.

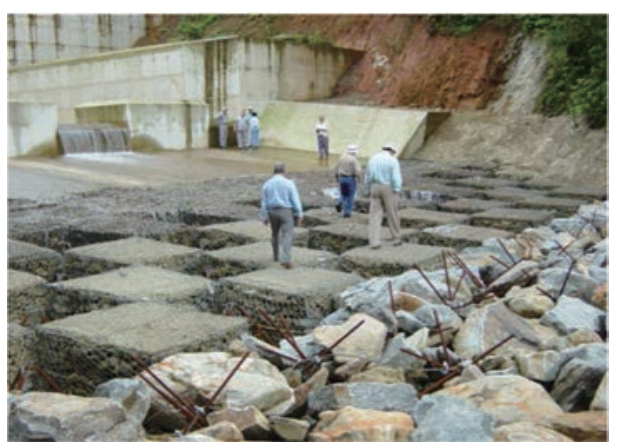

Photo 12 Flexible mantle of reinforced gabions to protect the foot of BF-2 dam.

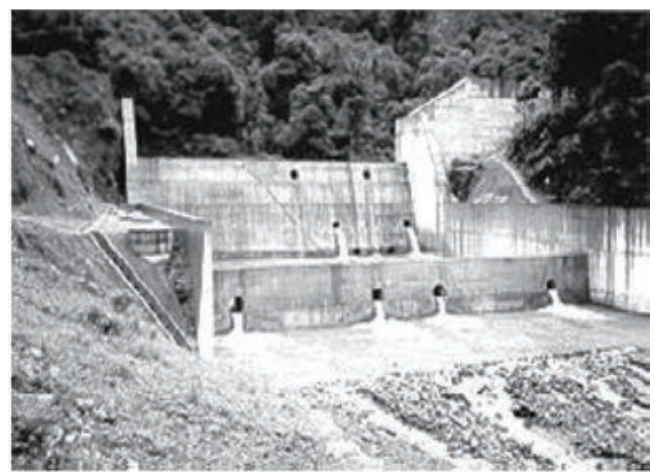

Photo 14 Main concrete dam (B 5) to retain large deposits, with holes to drain water.

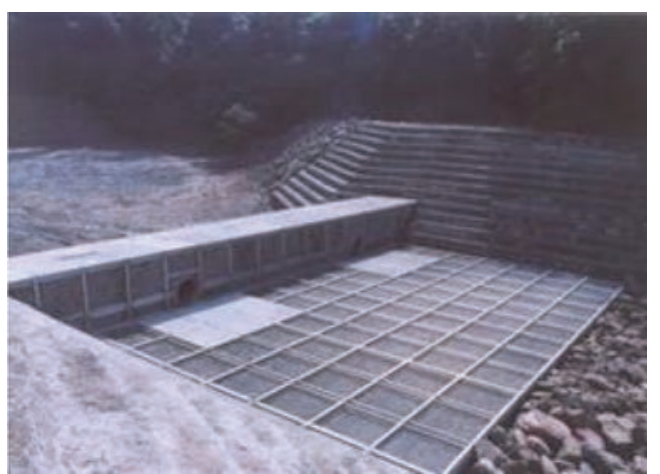

Photo 16 Steel frame dam (BS-2). filled with rockfill. 
International J ournal of Erosion Control Engineering Vol. 11, No. 3, 2019

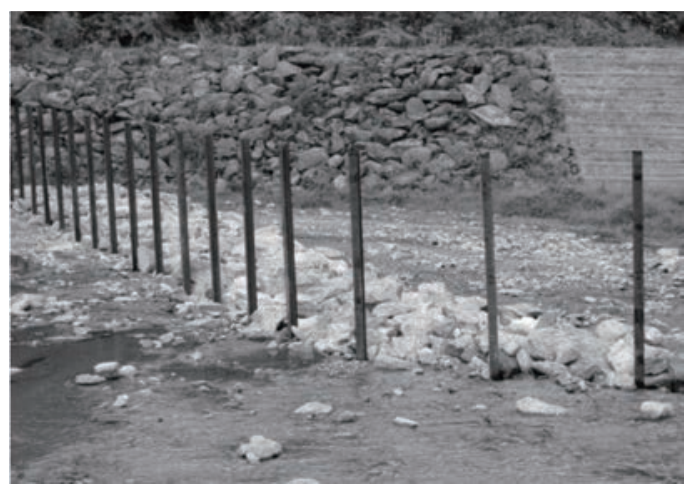

Photo 17 Vertical steel bars do retain trees and vegetation.

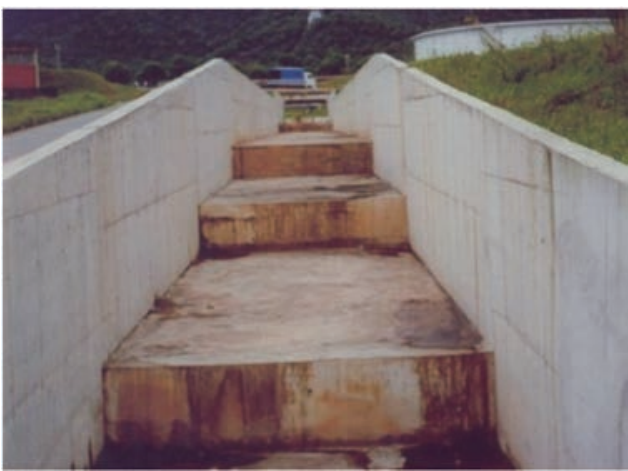

Photo 18 Channel to conduct the liquid mass to stilling basing and river.

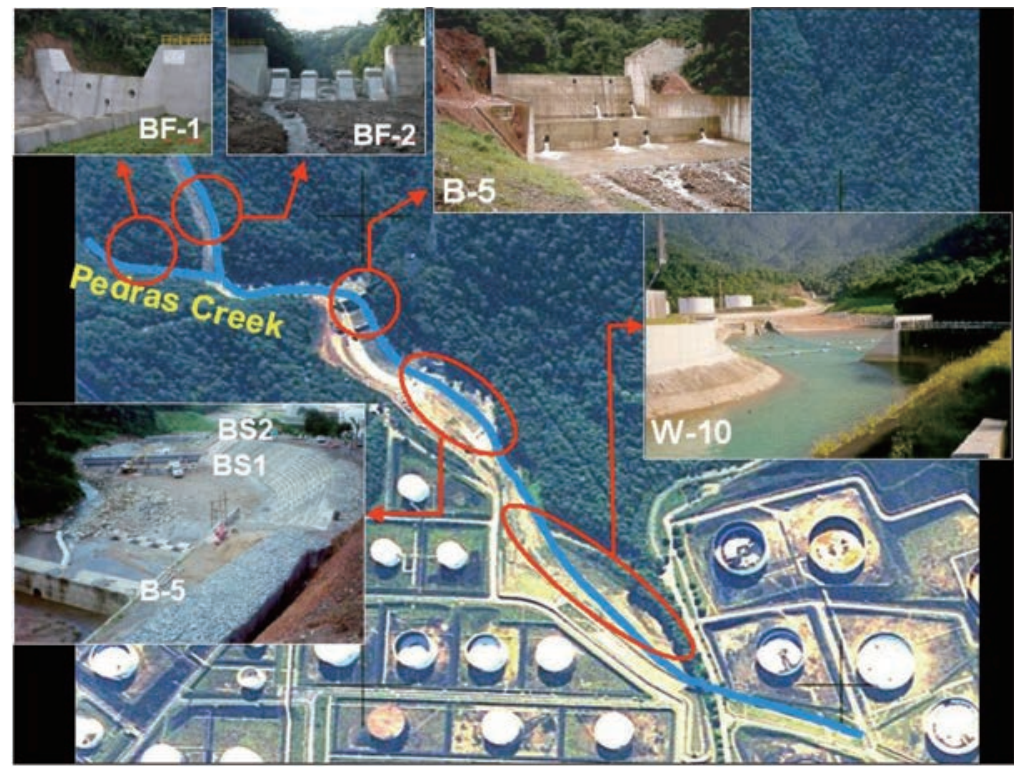

Photo 19 Control works for Cubatão R efinery - Upstream of W 10 Reservoir.

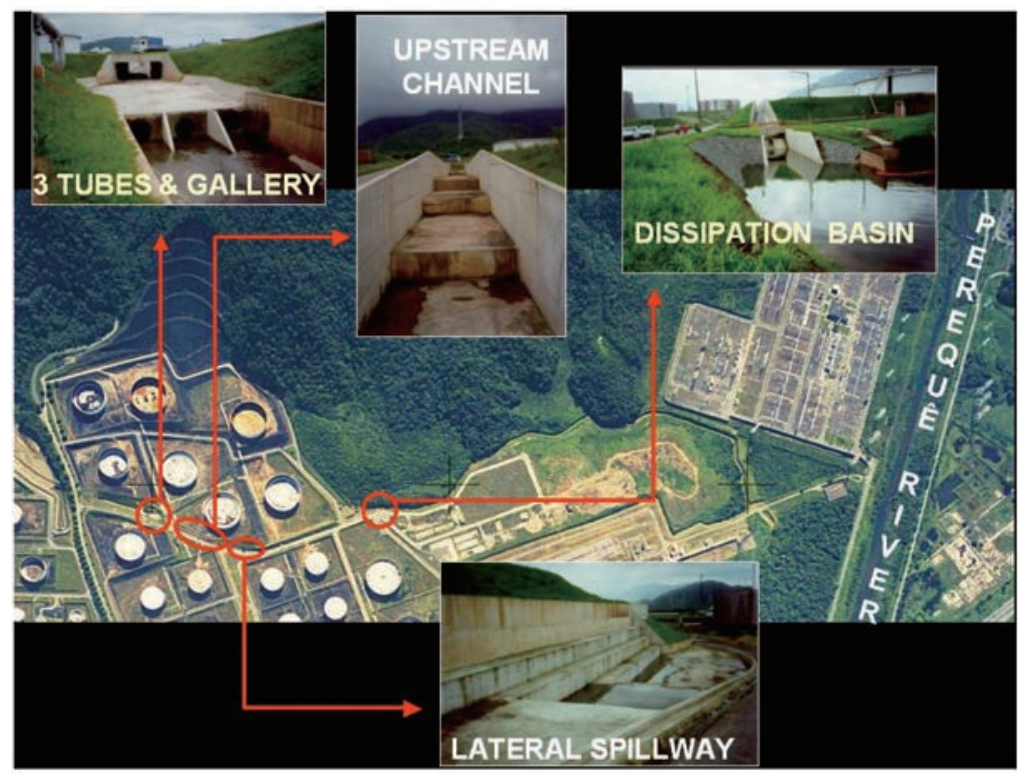

Photo 20 Control works for Cubatão Refinery - D ownstream of W 10 Reservoir. 
upstream from BF-2 dam, seven "stone collars" (Photo 7) were built along the stream, adequately spaced. Large rock boulders existing at the site, above 1.5 to $2 \mathrm{~m}$ in diameter, were perforated and linked by steel cables anchored in the river banks. Such collars retain rock fragments and create steps in the riverbed.

b) In two locations where bank erosion was occurring, concrete walls embedded in the alluvial foundations were built (Photo 9). In other river stretches, rockfill made of stones of large diameters and cemented with mortar (Photo 10) were built along the banks, providing substantial savings.

c) Finally, to retain tree logs, tree branches and leaves that fluctuate on the top of the moving mass and could trap the spillway of W 10 Reservoir, two structures were built. The first is a set of vertical steel rails, $3 \mathrm{~m}$ high, spaced $2 \mathrm{~m}$ from one another, fixed on top a concrete base, buried in the riverbed between BS-1 and BS-2 dams (Photos 17 and 19). The second structure is composed of 2 lines of floating drums with meshes, linked by cables that were anchored in shafts installed in the margin of W 10 Reservoir, in front of its spillway (Photo 19).

\section{ENVIRONMENT IMPACT}

All the above described "sabo works" were designed to protect the Refinery from the destructive power of debris flows. But collaterally they contemplate the natural environment. In fact, the ruin of an oil tank would lead to serious environmental problems. Furthermore, these "sabo works" were also intended to protect directly the natural environment. Before the 1994 debris flow the tributary of the Pedras River was an almost invisible creek in the forest. Today, its width reaches $40 \mathrm{~m}$ : due to erosion, the natural forest was devastated along its course.

The preservation of the environment is a constant concern of PETROBRAS and the proposed "sabo works" are in accordance with the principles that rule this type of Engineering throughout the world. The majority of the dams were built with local material, that is, local gravel and rock, encased in steel frames. The concrete and masonry dams will be surrounded by the natural forest. The access for the construction of the dams in the Pedras River and its tributary is along the river bed, with a minimum impact to the surroundings.

Finally, it is very important to observe "nature" and "sabo-works" performance after debris flows occurrence and to make adequate maintenance in order to secure that double protection.

\section{CONCLUDING REMARKS}

The art of designing "sabo works" requires a deep understanding of the phenomena of debris flows and the ability to anticipate their discharges, velocities and impact forces that will reach the engineering works. Each structure must be designed to achieve a specific goal and observation and maintenance are the key rules for a successive enterprise.

With respect to the design parameters required, as mentioned in the text, their adoption depends greatly of the historical knowledge of previous events, on the determination of probable rain intensity, on the empirical formulae derived from other events and some theoretical formulae.

Besides protecting the Refinery installations the proposed works will help in the preservation of environment, by inhibiting the occurrence of debris flows and heavy erosion along the rivers.

In summary, the art of designing these works demands creativity and interaction with the local conditions. JICA contributions and the technical visit carried out by some of the authors to Japan, in 1996, was important to implement the pioneer "sabo works" built in Cubatão.

ACK NOWLEDGMENT : The authors are indebted to PETROBRAS for the opportunity to present this paper, and for the incentives towards research that was possible to develop in the Escola Politécnica of São Paulo University, Brazil. They also manifest their gratitude to Prof. Takayasu Yamano, from Nihon University, Tokyo; Profs. Hiroshi Nakai, Kazuki Oda, Keiichiro Sonoda and Akitoshi Mochtizuki, from Osaka City University; and Profs. Hirotake Imamoto and Tamotsu Takahashi, from K yoto University, for their support during their technical visit to J apan, in November, 1996. They are also thankful to Biwa Lake Research Institute and Biwa Lake Work Office, in Shiga; Disaster Prevention Institute, in Kyoto; and Rokko Sabo Work Office, in Kobe for the information and the opportunity to visit "sabo works" in J apan.

\section{REFERENCES}

A raya M oya (1994) : Genesis de aluviones en la costa de zonas deserticas. In : I Simposio Panamericano de Deslizamientos -Guayaquil, Equador, pp. 186-200.

Cruz P. T. and M assad F. (1997) : Debris-Flows : an attempt to define design parameters. Proceedings, Symposium on Recent Developments on Soil Mechanics and Pavement M echanics, 25-27 th July, 1997, Rio de Janeiro, vol. I : 409414, Balkema.

Heumader, J. (2000) : Technical debris-flow countermeasures in A ustria. A review. Proceedings of the Second Int. Conf. on 
Debris-Flow Hazard Mitigation : M echanics, Prediction, and A ssessment. Taipei/Taiwan - 16-18 A ugust 2000.Balkema pp. 553-564.

Ikeya, H. (1976): "Introduction to Sabo Works". The Japan Sabo A ssociation. 168 pp.

Ikeya, H. (1989): "Debris Flow and its Countermeasures in Japan". Bull. IA EG 40, pp.15-33.

Jica (1991): "The Study on the Disaster Prevention and Restoration Projecrt in Serra do Mar, Cubatão Region, S. Paulo". January, 1991, vol. 2, Japan International Cooperation A gency.

Kanji M A, Cruz P T, Massad $F$ and A raujo Filho $H A$ de, (1997) : Basic and common characteristics of debris flows. Proceedings 2 nd Panamerican Symposium on Landslides and 20 . Congresso Brasileiro de Estabilidade de Encostas (COBRAE), November. Rio de Janeiro, Brasil, Vol $1: 232$ 240.

Legowo D, (1990) : Sabo Survey and Sabo Plan. Ministry of Public Works, Directorate of Rivers, Volcanic Sabo Technical Centre, JA PA N-JICA Publication, 54 pages.

Massad F, Cruz P. T, Kanji M A and Araujo Filho $\mathrm{H} \mathrm{A}$ de (1997) : Comparison between estimated and measured debris flow discharges and volume of sediments, Proceedings $2 \mathrm{nd}$
Panamerican Symposium on Landslides and 2 o. Congresso Brasileiro de Estabilidade de Encostas (COBRAE), N ovember 1997, Rio de Janeiro, B rasil, Vol 1, pp.213-222.

Mizuyama, T. and Ishikawa Y. (1988): Technical standard for the measures against debris flow (draft), Technical Memorandum of PWRI, No. 2632, Public Works Research Institute, M inistry of Construction, Japan, p 48

Rickenmann, D. (1991) : Hyperconcentrated flow and sediment transport at steep slopes, Journal of Hydraulic Engineering vol 117, n.11, Nov/1991, p. 1419-1439.

Suwa, H. (1989) : Field observation of debris-flow, Japan-China (Taipei) Joint Seminar on Natural Hazards Mitigation, K yoto, Japan, July 1989, 16-20 th, pp.343-352.

Takahashi, T. (1991): Debris flows, Monograph Series. Balkema, $165 \mathrm{p}$.

Takahashi T. (2007) : Debris flow: Mechanics, Prediction and Countermeasures. Taylor and Francis Group, London, UK, $448 \mathrm{p}$.

Received: 11 October, 2017

Accepted : 13 December, 2018 